\title{
PRESBYTERIAN DEPARTMENT OF CHURCH AND LABOR
}

\author{
By Rev. Charles Stelzle, Superintendent, \\ New York City.
}

Fully six times as many men in the labor unions of this country are not touched by the churches as are in all of the Presbyterian churches combined. Add to these the masses of non-unionists not in the Church and one will get some idea of the field in which the Department of Church and Labor is operating. Practically every immigrant is a working man. At any rate, he is in the working man class, using that term in the popular sense. Hence, the whole problem of the immigrant, social and religious, comes within the scope of the department, so far as the practical, every-day side of the question is concerned.

Socialism must be reckoned with by the Church. There are to-day nearly nine million socialist voters throughout the world. In our own country the gain by this party during the four years preceding the late Presidential election was sevenfold. If the increase during the next eight years is in the same ratio, the Socialists will elect a President of the United States. Whatever one may think of the economic value of Socialism or the probability of its success as a political party, this fact remains-Socialism has become to thousands of working men a substitute for the Church. Already in several of our American cities Souralist "Sundayschools" and "preaching services" are being held, conducted in some instances by deposed or discontented ministers and priests, They have adopted the vocabulary of the Church. They are insisting that Jesus Christ was .a Socialist, and that they more nearly represent the teachings of Jesus Christ than does Christianity socalled.

These, then, are some of the problems that confront us as a Church and as a nation. The labor question is fundamentally a moral and a religious question. It will never be settled upon any other basis. Therefore, the Church has a most important part in the solution of this world-problem. And because it is a world- 
problem, it must be studied in the most comprehensive manner. No little two by four scheme will solve this question.

It is the aim of the department to make it the best informed office in the world on the subjects which it is studying Into it comes, with almost every mail, from various and world-wide sources, the latest and most exact information affecting every phase of the working man problem, as it concerns the Church. Out of it goes, with even more frequency, by mail, messenger, telephone and telegram, the carefully digested and systematically tabulated information, to pastor and to Christian worker, to student and to teacher. There is a science in business-the result of co-ordinated experience. There should be a science of city missions. Christian workers should be spared the humiliation of blundering experiment. At the service of every minister and every member of the Presbyterian Church, and absolutely without charge, this phase of our work should become of increasing value to the whole Church.

So that both the Church and labor may see each other with clearer vision, the plan of the exchange of fraternal delegates between Ministers' Associations and Central Labor Unions has been adopted. The fraternal delegate goes unpledged to secrecy. $\mathrm{He}$ does not have the privilege of voting, but he has the right of the floor on all occasions. In some instances the labor unions have created the office of chaplain for the ministers, and the regular meetings are opened with prayer. Working together, the Ministers' Association and the Central Labor Union may bring about many municipal reforms. Indeed, united, there are few things in this direction which they may not accomplish in the cause of good citizenship, independent of partisan politics. Especially in those matters which involve moral issues-such as the saloon, gambling, the social evil, Sunday work, child labor, sanitary conditions in tenement houses and factories, and everything else that influences the moral life of the community-may these organizations cooperate. In operation in about one hundred cities, the plan is spreading from town to town, until it is hoped that it will become effective in the six hundred cities of our country that support Central Labor Unions and Ministers' Associations. The practical result of this plan has been that there is a more cordial relationship between working men and the Church; first, because the 
minister has a broader conception of what the labor movement stands for, and, second, because the labor leader has come to know something of the mission of the Church.

The department has just inaugurated a correspondence course in applied Christianity to meet the needs of ministers who are in difficult fields, especially in industrial centers.

There are over three hundred labor papers printed in this country. The influence of the labor press can hardly be overestimated. As a noted sociological writer recently declared, "The avarage working man reads his labor paper as the early Christian read his New Testament." Read by millions of working men who are eager for information affecting their interests, these molders of the laborer's opinion are leading on the great mass of men for good or ill. A press bureau, furnishing labor papers with original articles which present our viewpoint of the labor question, and discussing the working man's relation to the Church, is a part of the general plan of our department. In this way we have been speaking weekly to nearly three million trades unionists and their families, this making an audience of at least ten millions.

Every leaflet sent out by the department has been printed in this series. It has been an inexpensive way of getting information to the working men. If the Board of Home Missions were compelled to print in leaflet form the matter which is being sent to the labor press, and to pay the mail and express charges which would be necessary in order to send it to our workers, it would cost the board more each week than it costs to run the entire department for a whole year. We are sending more literature to the unchurched working men of the United States through these syndicate articles than is being sent out to the same class by all of the tract societies in the United States combined. There are about sixty such organizations. A labor leader of national reputation recently said that the influence of these articles has been such as to completely change the attitude of the labor press toward the Church.

In 1905 the Presbyterian General Assembly passed the following resolution:

"Appreciating the increasing importance of the industrial problem, and realizing that the labor question is fundamentally a moral and a religious question, and that it will never be settled upon any other basis, we recommend that the Presbyterial Home Mission Committees appoint sub-committees 
for the purpose of making a systematic study of the entire problem in their respective localities. These committees shall co-operate with the newlyorganized working men's department of the Board of Home Missions, thus establishing, in connection with the organized Presbyterianism of every city in America, a board of experts, who may be able to inform the churches with respect to the aims of organized labor, and to inform the workingmen concerning the mission of the Church. These committees shall also assist in the already successfully inaugurated plan of securing for the churches fraternal relationships with workingmen in their organizations; become responsible for the distribution of the literature issued by the board both for the membership of the Church and for the great mass of working men outside of the Church, and to push aggressively whatever methods may bring about 2 more cordial relationship between the Church and labor."

In accordance with this resolution, the department has in practically every large city of the United States special committees which represent it in the study of local problems. One of the newer features of the work of the department is the directing of great shop campaigns at the noon hour. During the past year the department directed campaigns in six cities, during sixty days, entering 400 shops, enlisting $5^{00}$ preachers, conducting 1,000 meetings, distributing 50,000 gospels, circulating 150,000 special programs and speaking to 200,000 working men.

Visiting cities requesting his services, the superintendent devotes himself largely to work in the field. Addressing the churches, men's clubs, missionary societies, young people's organizations, conferences, etc., he presents those phases of the work which seem to be most essential, and when it is desired he assists in the organization of definite lines of work which may be helpful in the community. Courses of lectures covering the question of the Church's relation to working men, and kindred subjects, are given to the students in theological seminaries, thus establishing a "traveling chair of Christian Sociology."

Labor unions are visited, mass meetings for working men are addressed in the churches, halls and theatres, the audience sometimes numbering from one thousand to ten thousand, and in every way possible efforts are made in local fields to bring the Church and the working man into closer fellowship. Conferences are also arranged for employers and employees for the discussion of industrial problems.

The pastors of the eleven thousand Presbyterian churches in (459) 
the United States are requested by the department each year to discuss some phase of the labor question on the Sunday preceding Labor Day. It is believed that just as Memorial Day and the several "Birthdays" show our appreciation of those who rendered patriotic service, and just as the Church's "Holy Days" do honor to those who have served mankind spiritually, so "Labor Sunday" should be observed by the churches in honor of the millions of toilers who daily serve mankind in the humbler places of life. This plan has the hearty endorsement of the leading central labor bodies of the country and of practically the entire labor press. Literature in the form of leaflets is largely employed, something like forty titles now being used both for the Church and for working men.

The following resolution, adopted by the American Federation of Labor, will indicate how this movement has been received by the highest court of organized working men:

"Whereas, The Presbyterian Church in the United States of America, at its last national convention, officially established a Department of Church and Labor for the express purpose of making a systematic study of the labor problem; and

"WhEREAS, It is part of the plan of the department to appoint in every industrial center special committees that may become experts in their knowledge of every phase of the labor movement, so that they may inform the churches with respect to the aims of organized labor; therefore be it

"Resolved, That the American Federation of Labor, in convention assembled, indorse this new and significant movement in the Prebsyterian Church; and we further recommend that central labor bodies co-operate with this department and with its sub-committees in every way that may be consistent, in order that the Church and the public at large may have a more intelligent conception of the conditions and aspirations of the toilers.

"Resolved, That the American Federation of Labor recommends that all affiliated State and central bodies exchange fraternal delegates with the various State and city ministerial associations, wherever practicable, thus insuring a better understanding on the part of the Church and the clergy of the aims and objects of the labor union movement of America." 